\title{
Effect of nitrogen content and additional straw on changes in chemical composition, volatile losses, and ammonia emissions from dairy manure during long-term storage
}

\author{
M. J. Aguerre,${ }^{*}$ M. A. Wattiaux,${ }^{* 1}$ T. Hunt, $†$ and N. E. Lobos ${ }^{\star}$ \\ *Department of Dairy Science, University of Wisconsin-Madison, Madison 53706 \\ †School of Agriculture, University of Wisconsin-Platteville, Platteville 53818
}

\begin{abstract}
Twelve 200-L barrels were used to determine the effects of $\mathrm{N}$ content and straw addition on changes in chemical composition and volatile losses measured by mass balance of dairy manure during a 136-d storage period. In addition, on $\mathrm{d} 0,3,6,12,28,56$, and 136 , rate of $\mathrm{NH}_{3}-\mathrm{N}$ emission was measured, and core samples were collected to characterize fermentation pattern. High N $(3.06 \% \mathrm{~N}, \mathrm{HN})$ and low N $(2.75 \% \mathrm{~N}, \mathrm{LN})$ manures were obtained from cows fed diets with 17.2 and $15.2 \%$ crude protein (dry matter basis), respectively. On d 0, manure scraped from a freestall barn floor was diluted with water to $10 \%$ dry matter and loaded in barrels with $(+S)$ or without $(-S)$ mixing $22 \mathrm{~g}$ of chopped wheat straw per kilogram of undiluted manure. Data were analyzed as a randomized complete block with a $2 \times 2$ factorial arrangement of treatments and 3 replications. We observed no interaction between treatments for the reported measurements, but several day-of-storage by treatment interactions were found. Throughout storage, total $\mathrm{NH}_{3}-\mathrm{N}$ (TAN, $\mathrm{NH}_{3}-\mathrm{N}+$ $\mathrm{NH}_{4}{ }^{+}-\mathrm{N} ; 71.9$ vs. $104.3 \mathrm{mg} / \mathrm{dL}$ ), $\mathrm{pH}$ (6.40 vs. 6.74 ), and total volatile fatty acids (TVFA, starting on d 12) were lower for $\mathrm{LN}$ relative to $\mathrm{HN}$ manure. In the presence of straw, crust formation occurred between d 12 and 28 , and $\mathrm{pH}$ became lower and TVFA became higher starting on d 56, compared with no straw. Treatments did not influence loss of organic matter, organic N, organic $\mathrm{C}$, or $\mathrm{N}$, which averaged $31,29,26$, and $20 \%$, respectively. However, neutral detergent fiber loss was $44 \%$ higher for $+\mathrm{S}$ relative to $-\mathrm{S}$ manure. Consistent reductions in the $\mathrm{C}: \mathrm{N}$ ratio indicated proportionally higher volatile $\mathrm{C}$ loss than volatile $\mathrm{N}$ loss during storage. Overall rate of $\mathrm{NH}_{3}-\mathrm{N}$ emission was $36 \%$ lower for LN than for HN manure. In the presence of straw, rate
\end{abstract}

Received August 16, 2011.

Accepted January 19, 2012.

${ }^{1}$ Corresponding author: wattiaux@wisc.edu of $\mathrm{NH}_{3}-\mathrm{N}$ emission did not differ until after crust formation, but was $67 \%$ lower on d 56 and $95 \%$ lower on d 136 , when it was barely detectable, compared with manure with no straw. Manure $\mathrm{pH}$ was highly correlated with TVFA:TAN ratio $(\mathrm{r}=-0.78)$, and rate of $\mathrm{NH}_{3}-\mathrm{N}$ emission was correlated with $\mathrm{pH}$, TVFA:TAN, TVFA, and TAN ( $\mathrm{r}=0.47,-0.44,-0.23$, and 0.28 , respectively). In this trial, both microbial fermentation and crust formation influenced $\mathrm{NH}_{3}-\mathrm{N}$ emission rate and other measured responses, highlighting the importance of long-term sampling to evaluate treatment effects in manure storage studies.

Key words: ammonia, manure storage, dairy

\section{INTRODUCTION}

Ammonia emission from livestock manure, which generates two-thirds of the anthropogenic release to the atmosphere worldwide (EPA, 2005; FAO, 2006), has a negative effect on human health, contributes to disturbance of natural ecosystems (Fangmeier et al., 1994), and decreases the value of manure as a fertilizer. In the United States, dairy cattle contribute $24 \%$ of total $\mathrm{NH}_{3}$ emissions from livestock manure (EPA, 2005). As the primary form of volatile $\mathrm{N}, \mathrm{NH}_{3}$ emission begins shortly after deposited feces and urine come into physical contact. Urinary urea is the primary source of volatized $\mathrm{NH}_{3}$ during the first days of storage (Thomsen, 2000) and thus measurements of $\mathrm{NH}_{3}$ loss in short-term storage trials (Paul et al., 1998; Krober et al., 2000) may not capture the effects of mineralization, which may account for 25 to $35 \%$ of organic N during long-term storage (Patni and Jui, 1991). In a review of literature, Rotz (2004) reported highly variable losses during storage ranging from 4 to $70 \%$. Although reducing excess $\mathrm{N}$ intake reduces manure $\mathrm{N}$ content, particularly urinary urea excretion (Broderick, 2003; Wattiaux and Karg, 2004), few studies (Kulling et al., 2001) have quantified the effect of manure $\mathrm{N}$ content on $\mathrm{NH}_{3}$ losses during long-term storage. The review of VanderZaag et al. (2008) suggested that substantial or almost complete 
suppression of $\mathrm{NH}_{3}$ emission could be obtained by using straw or other crop residues as a cover or when the presence of fibrous material resulted in a naturally occurring crust; however, Misselbrook et al. (2005a) reported no differences in $\mathrm{NH}_{3}$ emission from manure stored with or without bedding. Furthermore, the literature is unclear about the effect of covers on volatile $\mathrm{C}$ losses as methane and carbon dioxide (VanderZaag et al. 2008). Thus, uncertainties concerning the effect of manure $\mathrm{N}$ content are compounded with those associated with the presence of organic bedding on crust formation and subsequent $\mathrm{NH}_{3}$ emission and $\mathrm{C}$ losses during long-tem storage.

Therefore, the main objective of this study was to measure the effect of manure $\mathrm{N}$ content and the mixing of wheat straw in an amount equivalent to recommended bedding per stall for freestall barns on volatile losses $\left(\mathrm{C}\right.$ and $\mathrm{N}$ ) and rate of $\mathrm{NH}_{3}-\mathrm{N}$ emission during a 136-d storage period. An additional objective was to relate the rate of $\mathrm{NH}_{3}-\mathrm{N}$ emission to pattern of fermentation and changes in manure chemical composition during storage.

\section{MATERIALS AND METHODS}

\section{Manure Storage and Sampling}

This study was carried out at the Pioneer Farm, a systems-research farm, located at the University of Wisconsin, Platteville, which included a 4-row, drivethrough freestall barn with concrete floor and mattresses for bedding. During the trial, which took place from May 2006 to March 2007, a temperature-controlled shed (ClearSpan Fabric Structures International Inc., South Windsor, CT) with interior walls covered with reflective insulation (Tekfoil, TekSupply, Dyersville, IA) was constructed for storage of 200-L barrels (90 and $61 \mathrm{~cm}$ in height and circumference) used as longterm storage devices. Six-centimeter-diameter holes were drilled on a vertical axis 39,62 , and $86 \mathrm{~cm}$ from the top of each barrel to serve as sampling ports. These ports were mounted with $10-\mathrm{cm}$ polyvinyl chloride tubing $(5 \mathrm{~cm}$ i.d.) inserted halfway and sealed with silicone rubber sealant (DAP Inc., Baltimore, MD). The inner side of the sampling port was mounted with a collapsible $20-\mathrm{cm}$ polyethylene plastic tube $(6 \mathrm{~cm}$ i.d. $)$ to minimize sample losses before, during, and after collection. A sampling device was constructed with a 43.5-cm polyvinyl chloride tube $(2.6 \mathrm{~cm}$ i.d.) fitted with a plunger to allow for light suction when inserted in the sampling port (see photographs of equipment at http://dairynutrient.wisc.edu/gallery/Measurementof-Gaseous-Emissions-From-Stored-Manure).

\section{Diets, Manure Collection, and Treatments}

High $\mathrm{N}(\mathbf{H N})$ and low nitrogen $(\mathbf{L N})$ manures were obtained from 2 groups of cows (160 vs. 260 DIM) fed a diet including 47 and $52 \%$ forage (Table 1 ) and producing 36 and $27 \mathrm{~kg}$ of milk per cow per day, respectively. Diets were offered twice a day as TMR for negligible refusals. The HN and LN manure originated from cows fed a diet with 17.2 and $15.2 \%$ CP (DM basis) and consuming, on average, $678 \pm 40$ and $528 \pm 41 \mathrm{~g}$ of $\mathrm{N}$ per cow per day, as calculated from recorded feed offered and analyses of ration ingredients sampled on days of manure collection. The dietary chemical composition presented in Table 1 was from analytical procedures described below.

On d 0 of a 136-d storage period, manure from feeding alleys was allowed to accumulate for $6 \mathrm{~h}$ before being pushed to the end of the alleys with automatic scrapers, followed by hand scraping and thorough manual mixing. Manure was loaded in barrels, diluted with water (1.8:1 manure:water ratio), and mixed with $(+\mathbf{S})$ or without $(-\mathbf{S}) 22$ g of chopped wheat straw per kilogram of undiluted manure leading to 4 manure treatments $(\mathbf{L N}-\mathbf{S}, \mathbf{L N}+\mathbf{S}, \mathbf{H N}-\mathbf{S}$, and $\mathbf{H N}+\mathbf{S})$. This protocol was replicated on May 3, October 17, and October 27, 2006. The amount of straw per kilogram of undiluted manure was determined from recommended straw bedding per stall in the Midwestern United States (Midwest Plan Service, 1995) and the previously determined straw-to-manure ratio collected from the herd (Aguerre et al., 2010). Table 2 summarizes the amount of manure, diluting water, and added straw in each treatment. The chemical composition of wheat straw (Table 1) was derived from the analytical procedures described below.

\section{Chemical Composition on $d 0$ and 136}

On d 0 (immediately after loading the barrels) and d 136 of storage, samples were collected manually with a plastic cup from the same 3 locations (surface, middle, and bottom) in each barrel. After mixing, 2 representative subsamples were obtained; one was preserved with $60 \%$ sulfuric acid and the other was preserved without acidification before freezing at $-20^{\circ} \mathrm{C}$ for posterior analyses. The acidified samples were lyophilized in a Frezone 12 Freeze Dryer (Labonco Corp., Kansas City, $\mathrm{MO}$ ), and manure DM was calculated as the amount of sample recovered after lyophilization. Nonacidified manure samples were oven-dried at $60^{\circ} \mathrm{C}$ (forced-air oven) for $48 \mathrm{~h}$. Dry manure samples were ground through a 1-mm screen (Cyclone sample mill, Udy Corp., Fort Collins, CO). Lyophilized samples were analyzed for 
Table 1. Ingredients and chemical composition of the diets and composition of wheat straw $(\mathrm{n}=3)$

\begin{tabular}{|c|c|c|c|}
\hline \multirow[b]{2}{*}{ Item } & \multicolumn{2}{|c|}{ Diet } & \multirow{2}{*}{$\begin{array}{l}\text { Wheat } \\
\text { straw }\end{array}$} \\
\hline & Low CP & High CP & \\
\hline \multicolumn{4}{|l|}{ Ingredient, $\%$ of DM } \\
\hline Alfalfa baleage & 8.0 & 6.0 & - \\
\hline Alfalfa silage & 26.0 & 25.5 & - \\
\hline Corn silage & 17.9 & 15.4 & - \\
\hline High moisture corn & 31.0 & 25.4 & - \\
\hline Cottonseed & 7.9 & 7.9 & - \\
\hline Tallow & 0.4 & 0.4 & - \\
\hline Premix low ${ }^{1}$ & 6.9 & - & - \\
\hline Premix high $^{2}$ & - & 17.1 & - \\
\hline Mineral mix low ${ }^{3}$ & 1.6 & - & - \\
\hline Mineral mix high $^{4}$ & - & 2.2 & - \\
\hline Vitamins & 0.1 & 0.1 & - \\
\hline \multicolumn{4}{|l|}{ Composition } \\
\hline $\mathrm{DM},{ }^{5} \%$ of as-is & 57.1 & 56.3 & 95.4 \\
\hline Ash, $\%$ of DM & 6.7 & 7.1 & 9.8 \\
\hline $\mathrm{CP}, \%$ of $\mathrm{DM}$ & 15.2 & 17.2 & 5.7 \\
\hline $\mathrm{NDF}, \%$ of DM & 29.4 & 30.1 & 72.6 \\
\hline $\mathrm{NFC},{ }^{6} \%$ of DM & 44.6 & 41.6 & - \\
\hline
\end{tabular}

${ }^{1}$ Composition (\% of DM): Blood meal $2.3 \%$, starch $2.9 \%$, dried distiller corn $5.8 \%$, soy hulls $23 \%$, expeller soybean meal $28.8 \%$, and solvent soybean meal $37.4 \%$.

${ }^{2}$ Composition (\% of DM): Blood meal $2.6 \%$, soy hulls $13 \%$, expeller soybean meal $32.5 \%$, and solvent soybean meal $52.0 \%$.

${ }^{3}$ Each kilogram contained $116.0 \mathrm{~g}$ of $\mathrm{Ca}, 44 \mathrm{~g}$ of P, $211.0 \mathrm{~g}$ of NaCl, $135.0 \mathrm{~g}$ of Na, $0.028 \mathrm{~g}$ of $\mathrm{Co}, 2.79 \mathrm{~g}$ of $\mathrm{Mn}$, $0.02 \mathrm{~g}$ of Se, $3.5 \mathrm{~g}$ of Zn, 147,050 IU of vitamin A, 34,020 IU of vitamin D, and 1,304 IU of vitamin E.

${ }^{4}$ Each kilogram contained $147.0 \mathrm{~g}$ of $\mathrm{Ca}, 25 \mathrm{~g}$ of P, $121.0 \mathrm{~g}$ of NaCl, $125.0 \mathrm{~g}$ of Na, $0.023 \mathrm{~g}$ of $\mathrm{Co}, 2.79 \mathrm{~g}$ of $\mathrm{Mn}$, $0.02 \mathrm{~g}$ of Se, $3.5 \mathrm{~g}$ of Zn, 147,050 IU of vitamin A, 34,020 IU of vitamin D, and 1,304 IU of vitamin E.

${ }^{5}$ Oven-dried at $60^{\circ} \mathrm{C}$ (forced-air oven) for $48 \mathrm{~h}$.

${ }^{6}$ Calculated as $100-(\mathrm{NDF}+$ ether extract $+\mathrm{CP}+$ ash $)$, where ether extract was from Table 15.1 of NRC (2001).

total N (TN) and total C (TC) by combustion assay (Vario MAX CN analyzer, Elementar Analysensyteme $\mathrm{GmbH}$, Hanau, Germany), and ash was determined using a muffle furnace maintained at $550^{\circ} \mathrm{C}$ for $12 \mathrm{~h}$. Organic matter content was calculated as $100-$ ash. Neutral detergent fiber was determined on the nonacidified samples using $\alpha$-amylase (A3306, Sigma Chemical Co., St. Louis, MO) with sodium sulfite and corrected for ash concentration according to Van Soest et al. (1991), adapted for Ankom ${ }^{200}$ Fiber Analyzer (Ankom Technology, Faiport, NY).

\section{Mass Balance and N Mineralization}

The loss of the following fractions: DM, OM, TN, TC, and NDF during the $136 \mathrm{~d}$ of storage ( $\left.\mathrm{Y}_{\text {Loss }}\right)$ was estimated for each barrel by mass balance using the following equation: $Y_{\text {Loss }}(g)=A_{\text {in }}-A_{\text {out }}$, where $A_{\text {in }}$ is the amount of fraction $\mathrm{Y}$ in the barrel on $\mathrm{d} 0$ and $\mathrm{A}_{\text {out }}$ is the amount of fraction $\mathrm{Y}$ recovered from the barrel on $\mathrm{d}$ 136. The amount of fraction $\mathrm{Y}$ was calculated from the weight of mixed manure, water, and straw in the barrel, the percentage of DM, and the concentration

Table 2. Amounts $(\mathrm{kg}$, mean $\pm \mathrm{SD})$ of manure, ${ }^{1}$ diluting water, and wheat straw added to long-term storage barrels for each manure treatment on d $0(n=3)$

\begin{tabular}{lcccc}
\hline & \multicolumn{4}{c}{ Treatment $^{2}$} \\
\cline { 2 - 5 } Item & LN-S & LN+S & HN-S & HN+S \\
\hline Manure & $122.0 \pm 3.6$ & $120.4 \pm 3.5$ & $120.2 \pm 2.5$ & $115.6 \pm 1.1$ \\
Water & $65.9 \pm 0.9$ & $65.6 \pm 2.7$ & $66.9 \pm 1.8$ & $63.9 \pm 3.0$ \\
Straw & - & $2.6 \pm 0.076$ & - & $2.7 \pm 0.023$ \\
Total & $187.9 \pm 3.3$ & $187.6 \pm 1.4$ & $187.1 \pm 4.0$ & $181.8 \pm 3.3$ \\
\hline
\end{tabular}

${ }^{1}$ Manure scraped from the freestall barn floor.

${ }^{2} \mathrm{LN}=$ low $\mathrm{N}, \mathrm{HN}=\operatorname{high} \mathrm{N},+\mathrm{S}=$ straw addition, $-\mathrm{S}=$ no straw addition. 
of fraction $\mathrm{Y}$ in the DM. In addition, $\mathrm{N}$ mineralization was determined as the organic $\mathrm{N}$ mass balance calculated using the previous equation, where organic $\mathrm{N}$ was the difference between the amount of $\mathrm{TN}$ and the amount of total ammonia N (TAN; see below for analytical procedure), assuming that during manure storage, nonammonia inorganic $\mathrm{N}$ compounds were a negligible fraction of TN (Patni and Jui, 1991).

\section{Changes in Chemical Composition During Storage}

On d $0,3,6,12,28,56$, and 136 of storage, a single core sample was obtained from each sampling port. Temperature was recorded immediately with a digital thermometer (Fisher Scientific, Pittsburgh, PA), and the $\mathrm{pH}$ of a deionized water:manure mixture $(2: 1 \mathrm{ra}-$ tio) was measured for each sample using a calibrated portable $\mathrm{pH}$ meter (Twin pH-meter model B-213, Spectrum Technologies Inc., Plainfield, IL). After thorough mixing, a representative subsample was preserved with $60 \%$ sulfuric acid and frozen at $-20^{\circ} \mathrm{C}$ for posterior analyses. After thawing overnight at $5^{\circ} \mathrm{C}$, samples were extracted with a $2 \mathrm{M} \mathrm{KCl}$ solution. Approximately 3 $\mathrm{g}$ of manure was weighed and dissolved in $30 \mathrm{~mL}$ of $\mathrm{KCl}$ in a polyethylene tube. The tube was shaken for $90 \mathrm{~min}$ at $150 \mathrm{rpm}$ in an orbital shaker (VWR International, West Chester, PA) and centrifuged at 7,443 $\times g$ for $10 \mathrm{~min}$. The supernatant was transferred to $90-\times$ $100-\mathrm{mm}$ polyethylene test tubes and stored at $-20^{\circ} \mathrm{C}$. These samples were analyzed later for TAN $\left(\mathrm{NH}_{3}-\mathrm{N}+\right.$ $\mathrm{NH}_{4}{ }^{+}-\mathrm{N}$ ) concentration by colorimetric assay (Chaney and Marbach, 1962) and total VFA (TVFA: acetate, propionate, butyrate, isobutyrate, valerate, and isovalerate) concentration by gas-liquid chromatography (Perkin Elmer Autosystem, Norwalk, CT).

\section{Ammonia-N Emission}

The $\mathrm{NH}_{3}-\mathrm{N}$ emitted from each barrel over a 2 -h period on d $0,3,6,12,28,56$, and 136 of storage was collected by using a dynamic chamber following a procedure adapted from Misselbrook et al. (2005a). Modified circular lids with a centrally located fan (model DB200, Suncourt Inc., Durant, IA; $0.10 \mathrm{~m}$ in diameter) drew air across the manure surface through 4 inlet holes $(0.025 \mathrm{~m}$ in diameter) cut at regular intervals around the perimeter and through the top of the lid. Air passed through the headspace of the manure storage, and the concentration of $\mathrm{NH}_{3}-\mathrm{N}$ was determined by drawing a subsample of the air exiting the central fan with a vacuum pump at a flow rate of $2 \mathrm{~L} / \mathrm{min}$. The flow rate was controlled using a FR2000 Series flow meter (Cole-Palmer Instrument Co., Vernon Hills, IL). Air samples were collected using Teflon tubing to minimize adsorption of $\mathrm{NH}_{3}-\mathrm{N}$. Acid-coated glass wool (soaked for $1 \mathrm{~h}$ in $3 \%$ tartaric acid solution in methanol) was placed across the inlet holes to remove any $\mathrm{NH}_{3}-\mathrm{N}$ from the inlet air. The glass wool was replaced at the beginning of each measurement. A blank barrel was used to account for $\mathrm{NH}_{3}-\mathrm{N}$ in inlet air that might not be captured by the acid-coated glass wool. Sampled air flowed through an absorption flask containing $30 \mathrm{~mL}$ of $0.02 \mathrm{M}$ orthophosphoric acid. Concentration of $\mathrm{NH}_{4}{ }^{+}-\mathrm{N}$ captured in the absorption flask was determined by colorimetric assay (Chaney and Marbach, 1962). Air velocity through the central duct of the lid was measured using a hand-held anemometer (Digital Thermo Wind Meter, Spectrum Technologies Inc.). Average air velocity through the central duct was measured at 9 different locations over the duct using a slight modification of the log-linear traverse method (ASHRAE Handbook, 1993). Airflow was calculated as the product of the air velocity through the central duct $(\mathrm{m} / \mathrm{h})$, the cross-sectional area of the duct $\left(\mathrm{m}^{2}\right)$, and the duration of the 2-h collection period. Concentration of $\mathrm{NH}_{3}-\mathrm{N}$ in the outlet air $\left(\mathrm{g} / \mathrm{m}^{3}\right)$ from the barrels was determined as follows:

$$
\mathrm{NH}_{3}-\mathrm{N}_{\text {outlet air }}=\left(\mathrm{NH}_{3}-\mathrm{N}_{\text {flask }} \times \text { volume }_{\text {acid }}\right) / \text { volume }_{\text {air }},
$$

where $\mathrm{NH}_{3}-\mathrm{N}_{\text {flask }}$ is the concentration of $\mathrm{NH}_{3}-\mathrm{N}$ in the absorption flask $(\mathrm{g} / \mathrm{L})$, volume acid is the volume of orthophosphoric acid in the absorption flask (L), and volume $_{\text {air }}$ is the volume of sampled air $\left(\mathrm{m}^{3}\right)$.

The amount of $\mathrm{NH}_{3}-\mathrm{N}$ emitted in the 2-h collection period $(\mathrm{g})$ was calculated as the product of the $\mathrm{NH}_{3}-\mathrm{N}$ concentration in the outlet air $\left(\mathrm{g} / \mathrm{m}^{3}\right)$ and the airflow $\left(\mathrm{m}^{3}\right)$ through the central duct of the lid during the collection period. The emission rate from the manure surface $\left(\mathrm{g} / \mathrm{m}^{2}\right.$ per $\left.\mathrm{h}\right)$ was adjusted for $\mathrm{NH}_{3}-\mathrm{N}$ emission of the blank. In addition, emission rates for each sampling day were extrapolated to a 24 -h period, and the area under the curve (AUC) was integrated over the 136-d storage using the trapezoidal method. The main purpose of calculating AUC was to evaluate predicted emission derived from dynamic chambers measurements to actual TN loss measured by mass balance.

\section{Statistical Design and Analyses}

The experiment was conducted as a randomized complete block. A block was defined by a set of 4 barrels within which treatments were arranged in a $2 \times$ 2 factorial. Manure composition on d 0 and 136, mass balance data (amounts on d 0 and 136 and losses during storage), and AUC data were analyzed with the 
Mixed procedure (SAS Institute, 2004) with the following model:

$$
\mathrm{Y}_{\mathrm{ijk}}=\mu+\mathrm{B}_{\mathrm{i}}+\mathrm{N}_{\mathrm{j}}+\mathrm{S}_{\mathrm{k}}+\mathrm{N}_{\mathrm{j}} \times \mathrm{S}_{\mathrm{k}}+\mathrm{e}_{\mathrm{ijk}},
$$

where $Y_{i j k}$ is the dependent variable, $\mu$ is the overall mean, $B_{i}$ is the effect of block ( $\mathrm{i}=1$ to 3 ), $\mathrm{N}_{\mathrm{j}}$ is the effect of manure $\mathrm{N}(\mathrm{j}=1$ to 2$), \mathrm{S}_{\mathrm{k}}$ is the effect of straw ( $\mathrm{k}$ $=1$ to 2$), \mathrm{N}_{\mathrm{j}} \times \mathrm{S}_{\mathrm{k}}$ is the interaction between manure $\mathrm{N}$ and straw, and $e_{i j k}$ is the residual error. All terms were considered fixed except for block and residual error.

The above model was expanded to include effect of day, manure $\mathrm{N} \times$ day interaction, and straw $\times$ day interaction to determine treatment effects on $\mathrm{pH}$, TAN, TVFA, and $\mathrm{NH}_{3}-\mathrm{N}$ emission rate. All terms were considered fixed except for block and residual error. The spatial power covariance structure was used to fit a time-series type covariance structure in which the correlation declines as a function of time. Pearson correlation coefficients were used to study the association between $\mathrm{NH}_{3}-\mathrm{N}$ emission rate, temperature, $\mathrm{pH}$, TAN, and TVFA. To evaluate the treatment effect for measurements performed at different depth of the barrels (temperature, pH, TVFA, and TAN), data from each sampling day were analyzed separately with the effect of depth of sampling ( $\mathrm{n}=1$ to 3 ) added to the model described above. Significance was declared at $P$ $\leq 0.05$ and tendency for $0.05<P \leq 0.10$. For repeated measurements, treatment differences at individual days were assessed using the SLICE option when manure N $\times$ day or straw $\times$ day interactions were significant.

\section{RESULTS}

The interaction between manure $\mathrm{N}$ and straw did not reach significance for any of the reported measurements $(P=0.19$ to $P=0.95)$. Thus, main effects only will be reported and discussed.

\section{Chemical Composition on $d 0$ and 136}

Manure $N$ Level. As anticipated, on d 0, the TN content was lower for $\mathrm{LN}$ than for $\mathrm{HN}$ manure and averaged 2.75 and $3.06 \%$ of DM, respectively (Table 3 ). This difference persisted during storage as TN increased to 3.06 and $3.44 \%$ of DM for $\mathrm{LN}$ and $\mathrm{HN}$, respectively, on d 136. Furthermore, the chemical form of $\mathrm{N}$ differed between treatments. On $\mathrm{d} 0$, a greater portion of $\mathrm{TN}$ was in the organic form and TAN was lower in LN manure compared with HN manure (82 vs. $77 \%$ of TN and 53.7 vs. $80.0 \mathrm{mg} / \mathrm{dL}$, respectively). However, after $136 \mathrm{~d}$ of storage, organic $\mathrm{N}$ in $\mathrm{TN}$ was reduced to an average of $70 \%$ for both treatments, whereas TAN had increased, with HN maintaining a higher concentration of TAN compared with LN manure (85.1 vs. 120.5 $\mathrm{mg} / \mathrm{dL}$, respectively). The OM content on d 0 was not influenced by manure $\mathrm{N}$ level, but was higher for LN relative to HN manure on d 136 ( 81.8 vs. $80.1 \%$ of DM, respectively).

Addition of Straw. Dry matter and NDF contents were higher for $+\mathrm{S}$ than for $-\mathrm{S}$ manure on d 0 (12.0 vs. 10.1 and 44.7 vs. $38.3 \%$ of $\mathrm{DM}$, respectively), but not on d 136. On d 0 , TN content was lower for $+\mathrm{S}$ than for

Table 3. Chemical composition of manure treatments on d 0 and 136 of storage

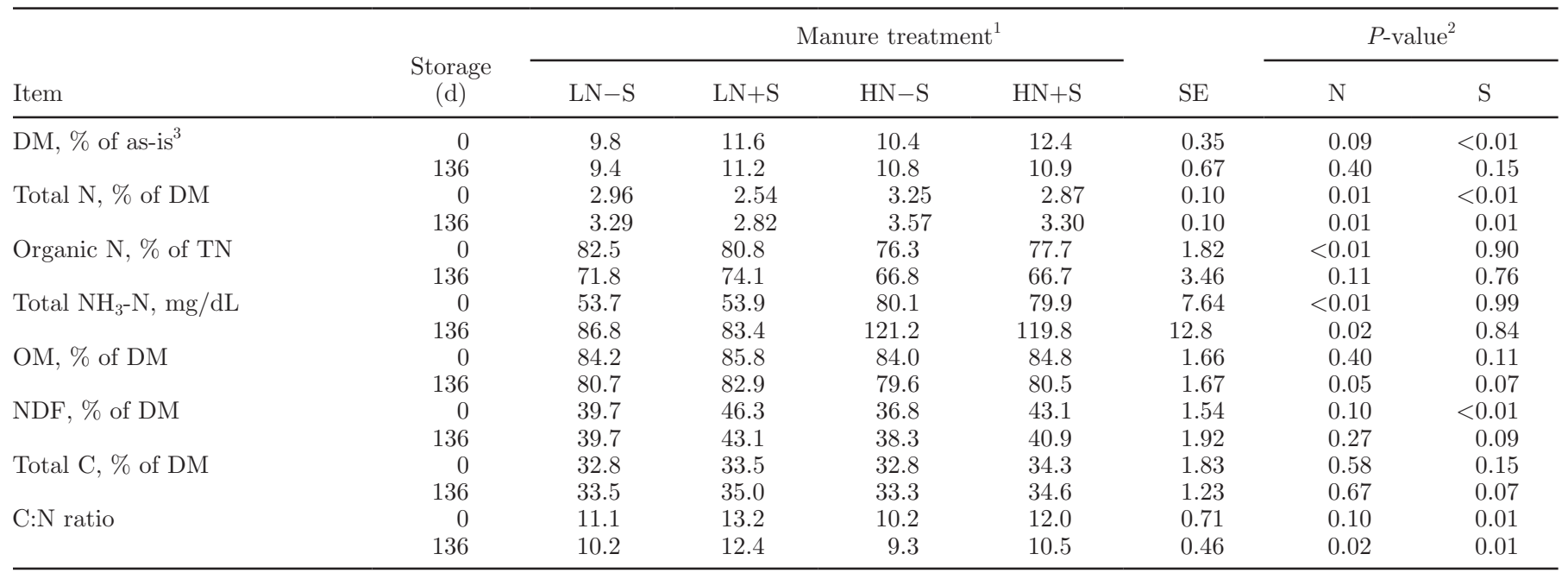

${ }^{1} \mathrm{LN}=$ low $\mathrm{N}, \mathrm{HN}=$ high $\mathrm{N},+\mathrm{S}=$ straw addition, $-\mathrm{S}=$ no straw addition.

${ }^{2} \mathrm{~N}=$ effect of nitrogen level; $\mathrm{S}=$ effect of straw addition.

${ }^{3}$ Manure DM obtained by freeze-drying stored wet manure. 
$-\mathrm{S}$ manure (2.71 and $3.11 \%$ of $\mathrm{DM}$, respectively) and this difference persisted on $\mathrm{d} 136$. Moreover, the OM content, which averaged $84.7 \%$ of DM on d 0 , tended to be higher for $+\mathrm{S}$ compared with $-\mathrm{S}$ manure on d 136 ( 81.7 vs. $80.2 \%$ of $\mathrm{DM}$, respectively).

Difference in Composition. Calculated by difference between d 136 and d 0 (Table 3), DM content did not change substantially during storage (11.1 vs. $10.6 \%$ of as-is on d 0 and 136, respectively); however, TN content increased from 2.91 to $3.25 \%$ of DM (a $12 \%$ increase) and TAN content increased from 66.9 to 103 $\mathrm{mg} / \mathrm{dL}$ (a $54 \%$ increase), whereas organic $\mathrm{N}$ content decreased from 79.5 to $70 \%$ of $\mathrm{TN}$ (a $12 \%$ reduction). Furthermore, during the $136 \mathrm{~d}$ of storage, OM content decreased from 84.7 to $80.9 \%$ (a $5 \%$ reduction) and NDF content decreased from 41.5 to $40.5 \%$ of the DM (a $2 \%$ reduction). These compositional changes were not influenced by treatments, except for OM, which had greater disappearance during storage for HN relative to LN treatment (4.4 vs. $3.3 \%$ of DM, respectively, $P=0.01$; data not shown).

\section{Mass Balance and N Mineralization}

Storage losses obtained by mass balance are presented in Table 4. Overall, the percentage losses were as follows: wet manure 24\%, DM $27 \%$, OM $31 \%$, TN $20 \%$, organic N 29\%, TC 26\%, and NDF 23\%. Treatment effects were as follows.

Manure $\mathbf{N}$ Level. On d 0, barrels loaded with LN manure contained similar amounts of DM, OM, and TC; they tended to contain more NDF (6,563 vs. 5,999 g), but contained $14 \%$ less TN (548 vs. $639 \mathrm{~g}$ ), and $9 \%$ less organic N (447 vs. $491 \mathrm{~g}$ ) than barrels filled with HN manure. After $136 \mathrm{~d}$ of storage, however, TN was the only chemical fraction that was recovered in a lower amount in LN relative to $\mathrm{HN}$ manure (445 vs. $507 \mathrm{~g}$, respectively). Manure $\mathrm{N}$ level had no effect on storage losses of any chemical fractions measured by mass balance. The loss of TN was, however, reduced by $22 \%$ for LN relative to HN manure (103 vs. 132 g, respectively; $P=0.28)$.

Addition of Straw. On d 0, barrels containing the $+\mathrm{S}$ manure had similar amounts of $\mathrm{TN}$ and organic $\mathrm{N}$, but higher amounts of DM (22.2 vs. $19.0 \mathrm{~kg}), \mathrm{OM}$ (18.8 vs. $16.0 \mathrm{~kg}), \mathrm{TC}(7.5$ vs. $6.2 \mathrm{~kg})$, and NDF $(6,984$ vs. $5,579 \mathrm{~g}$ ) than barrels containing the $-\mathrm{S}$ manure. After $136 \mathrm{~d}$ of storage, the former treatment still had a higher amount of DM (15.7 vs. $14.2 \mathrm{~kg} ; P=0.06)$, OM (12.8 vs. $11.4 \mathrm{~kg})$, and TC (5.5 vs. $4.6 \mathrm{~kg})$, but similar amounts of TN, organic N, and NDF compared with the latter. Addition of straw had no effect on storage losses of any chemical fraction measured by mass balance except for NDF, for which the loss was $79 \%$

Table 4. Effect of manure treatments on losses measured by mass balance after $136 \mathrm{~d}$ of storage

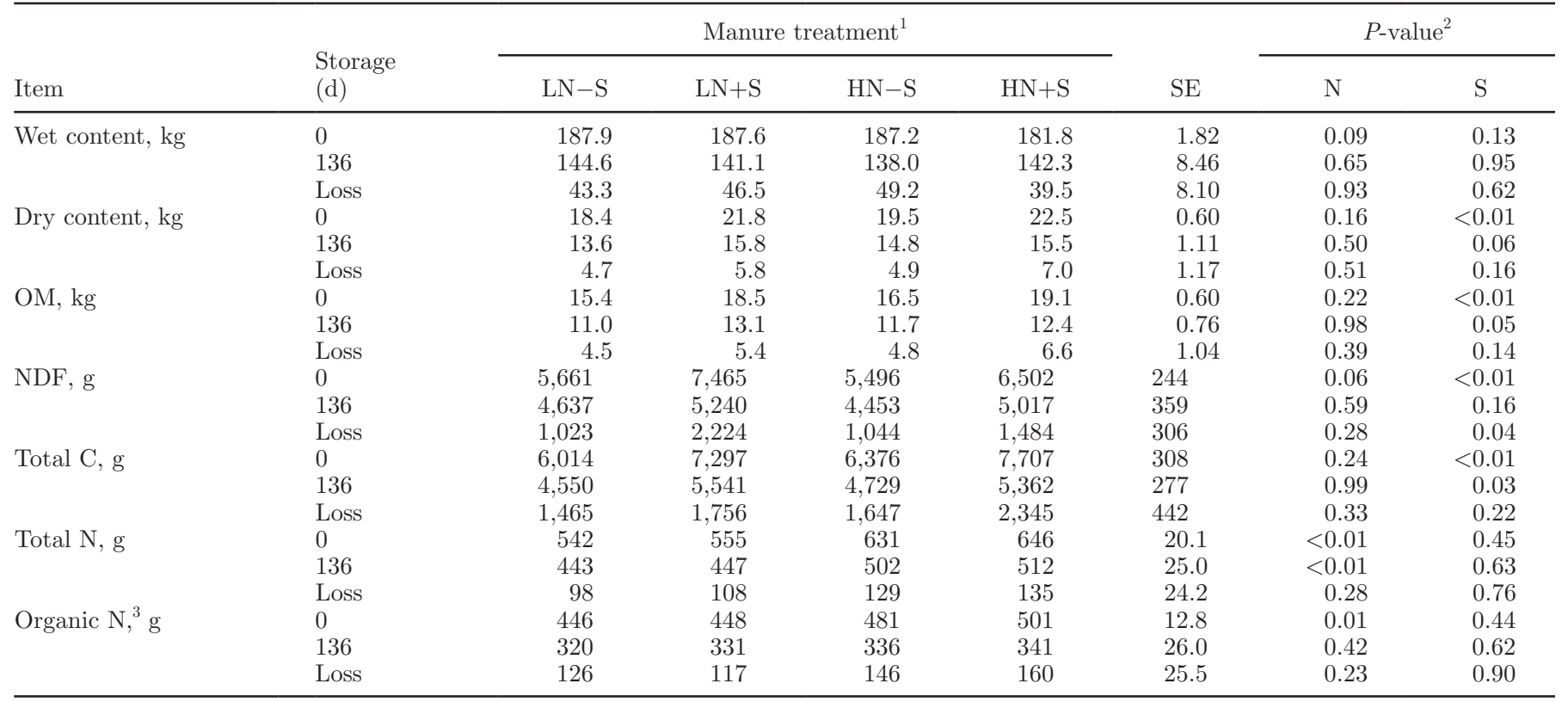

${ }^{1} \mathrm{LN}=$ low $\mathrm{N}, \mathrm{HN}=$ high $\mathrm{N},+\mathrm{S}=$ straw addition, $-\mathrm{S}=$ no straw addition.

${ }^{2} \mathrm{~N}=$ effect of nitrogen level; $\mathrm{S}=$ effect of straw addition.

${ }^{3}$ Organic $\mathrm{N}$ loss was used as an estimator of $\mathrm{N}$ mineralization during storage. 
higher for $+\mathrm{S}$ compared with $-\mathrm{S}$ treatment (1,854 vs. $1,034 \mathrm{~g})$.

\section{Changes in Chemical Composition During Storage}

Average values of the 3 sampling depths were used to determine the effects of manure treatment on change in temperature, $\mathrm{pH}$, TVFA, and TAN throughout storage. Manure temperature was not influenced by treatment, but reflected ambient temperature, which averaged 17.5 $\pm 3.3^{\circ} \mathrm{C}$ and ranged from 12.2 to $24.3^{\circ} \mathrm{C}$. In contrast, during the first $56 \mathrm{~d}$ of storage, $\mathrm{pH}$ declined from 8.15 to 5.94 , TVFA increased from 38.0 to $192.5 \mathrm{mM}$, and TAN increased from 66.8 to $100.7 \mathrm{~m} M$. These changes were influenced by treatments as illustrated in Figure 1 , which also depicted a distinct long-term effect from d 56 to 136.

Manure $\boldsymbol{N}$ Level. The pH, TVFA, and TAN were influenced by manure $\mathrm{N}$ level and days of storage (Figure $1 \mathrm{a}, \mathrm{b}$, and c). Values remained consistently lower and averaged 6.40 versus $6.74 \mathrm{pH}$ unit, 116 versus 138 $\mathrm{m} M$ TVFA, and 71.9 versus $104.3 \mathrm{mg} / \mathrm{dL}$ TAN, for LN compared with HN manure, respectively (all $P<0.01$ ). The pattern of change during storage can be outlined as follows. A sharp decline in $\mathrm{pH}$ was observed during the first $12 \mathrm{~d}$. Conversely, the pattern of change in TVFA and TAN was characterized by a sharp increase during the first $12 \mathrm{~d}$ of storage. Although the nadir in $\mathrm{pH}$ corresponded to the TVFA peak on d 56 (Figures $1 \mathrm{a}$ and $1 \mathrm{~b}$ ), TAN did not stop increasing before the end of the trial (Figure 1c). A significant interaction between manure $\mathrm{N}$ level and days of storage $(P=0.012)$ revealed that TVFA concentration was higher for HN than for LN manure on d 26, 56, and 136.

Addition of Straw. As illustrated by Figures 1d and $1 \mathrm{e}$, addition of straw did not influence manure $\mathrm{pH}$ and TVFA during the first $28 \mathrm{~d}$ of storage. However, the $\mathrm{pH}$ of $+\mathrm{S}$ was lower than that of $-\mathrm{S}$ manure on $\mathrm{d}$ 56 (5.73 vs. $6.14 ; P<0.01$ ) and d 136 (5.90 vs. 6.75 ; $P<0.01$ ), whereas TVFA was higher in $+\mathrm{S}$ than in $-\mathrm{S}$ manure on $\mathrm{d} 56(203$ vs. $182 \mathrm{~m} M ; P=0.06)$ and $\mathrm{d}$ 136 (216 vs. $151 \mathrm{mM}$; $P<0.01$ ). In both treatments, TAN increased throughout the entire storage period in a similar pattern (Figure 1f).

\section{Stratification}

Depth of sampling had no effect on temperature, TVFA, or TAN. However, starting between d 12 and 28 and continuing until the end of the trial, a divergent stratification pattern emerged for manure $\mathrm{pH}$ (Figure 2 ). On d 28 , manure $\mathrm{pH}$ closest to the surface (top) was higher for $-\mathrm{S}$ treatment compared with $+\mathrm{S}$ (6.28 vs. 5.67 , respectively). This surface manure $\mathrm{pH}$ differen- tial between treatments became greater on d 56 (6.39 vs. 5.55 for $-\mathrm{S}$ and $+\mathrm{S}$, respectively) and reached the maximum difference on $\mathrm{d} 136$ (7.11 vs. 6.02 for $-\mathrm{S}$ and $+\mathrm{S}$, respectively).

\section{Ammonia-N Emission}

Overall, the headspace (mean height between stored manure and the lid) was $0.20 \pm 0.05 \mathrm{~m}$ (mean $\pm \mathrm{SD})$, air velocity over the manure surface was $0.10 \pm 0.03$ $\mathrm{m} / \mathrm{s}$, and average headspace turnover per minute was $21.1 \pm 7.0$. With increasing days of sampling, the headspace generally increased due to water and DM loss, and thus headspace turnover per minute decreased, from $20.8 \pm 1.9$ on d 0 to $14.0 \pm 2.4$ on d 136 .

Manure $\boldsymbol{N}$ Level. Rates of $\mathrm{NH}_{3}-\mathrm{N}$ emission were numerically higher on each sampling day (Figure 3a), and the 136-d average was $36 \%$ lower for $\mathrm{LN}$ relative to $\mathrm{HN}$ treatment $\left(0.32\right.$ vs. $0.50 \mathrm{~g} / \mathrm{m}^{2}$ per $\left.\mathrm{h} ; P<0.02\right)$. The pattern of change over time was similar between manure $\mathrm{N}$ levels (Figure 3a). For both treatments, the highest $\mathrm{NH}_{3}-\mathrm{N}$ emission rate was detected on $\mathrm{d} 0(0.63$ $\pm 0.24 \mathrm{~g} / \mathrm{m}^{2}$ per $\left.\mathrm{h}\right)$; it declined to a nadir on d $6(0.27$ $\pm 0.15 \mathrm{~g} / \mathrm{m}^{2}$ per $\mathrm{h}$ ) and returned to $74 \%$ of the $\mathrm{d} 0$ emission rate on d $12\left(0.47 \pm 0.15 \mathrm{~g} / \mathrm{m}^{2}\right.$ per $\left.\mathrm{h}\right)$ and thereafter declined again to $66 \%$ of d 0 emission after $136 \mathrm{~d}$ of storage $\left(0.42 \pm 0.49 \mathrm{~g} / \mathrm{m}^{2}\right.$ per $\left.\mathrm{h}\right)$. The AUC cumulative $\mathrm{NH}_{3}-\mathrm{N}$ loss (g) tended to be lower for LN than for HN (225 vs. $294 \mathrm{~g}$, respectively; $P=0.07$ ).

Addition of Straw. Overall, the $\mathrm{NH}_{3}-\mathrm{N}$ emission rate was lower for $+\mathrm{S}$ relative to $-\mathrm{S}$ manure (0.34 vs. $0.47 \mathrm{~g} / \mathrm{m}^{2}$ per h; $P=0.07$; Figure $\left.3 \mathrm{~b}\right)$. However, we observed an interaction between straw addition and day of storage, because the $\mathrm{NH}_{3}-\mathrm{N}$ emission rate was not influenced by straw during the first $28 \mathrm{~d}$ of storage but was higher for $-\mathrm{S}$ relative to $+\mathrm{S}$ manure on d $56(0.48$ vs. $0.16 \mathrm{~g} / \mathrm{m}^{2}$ per h) and $\mathrm{d} 136$ (0.80 vs. $0.04 \mathrm{~g} / \mathrm{m}^{2}$ per h). Thus, $\mathrm{NH}_{3}-\mathrm{N}$ emission rate was the lowest recorded for $+\mathrm{S}$ but highest recorded for $-\mathrm{S}$ manure on $\mathrm{d} 136$ of storage. The AUC cumulative $\mathrm{NH}_{3}-\mathrm{N}$ emission rate was reduced by $70 \%$ for $-\mathrm{S}$ compared with $+\mathrm{S}$ manure (398 vs. $121 \mathrm{~g}$, respectively; $P<0.001)$.

\section{Correlations}

Table 5 summarizes correlations among chemical characteristics of the 4 manure treatments using data from all sampling time $(\mathrm{n}=84)$. Rate of $\mathrm{NH}_{3}-\mathrm{N}$ emission was most highly correlated with manure $\mathrm{pH}(\mathrm{r}=$ 0.47 ), but was correlated also with TAN, TVFA, and TVFA:TAN ratio. In turn, manure $\mathrm{pH}$ was most highly correlated with TVFA:TAN ratio $(\mathrm{r}=-0.78)$, but was also correlated with TVFA and temperature. Furthermore, TAN was most highly correlated with TVFA $(r=$ 

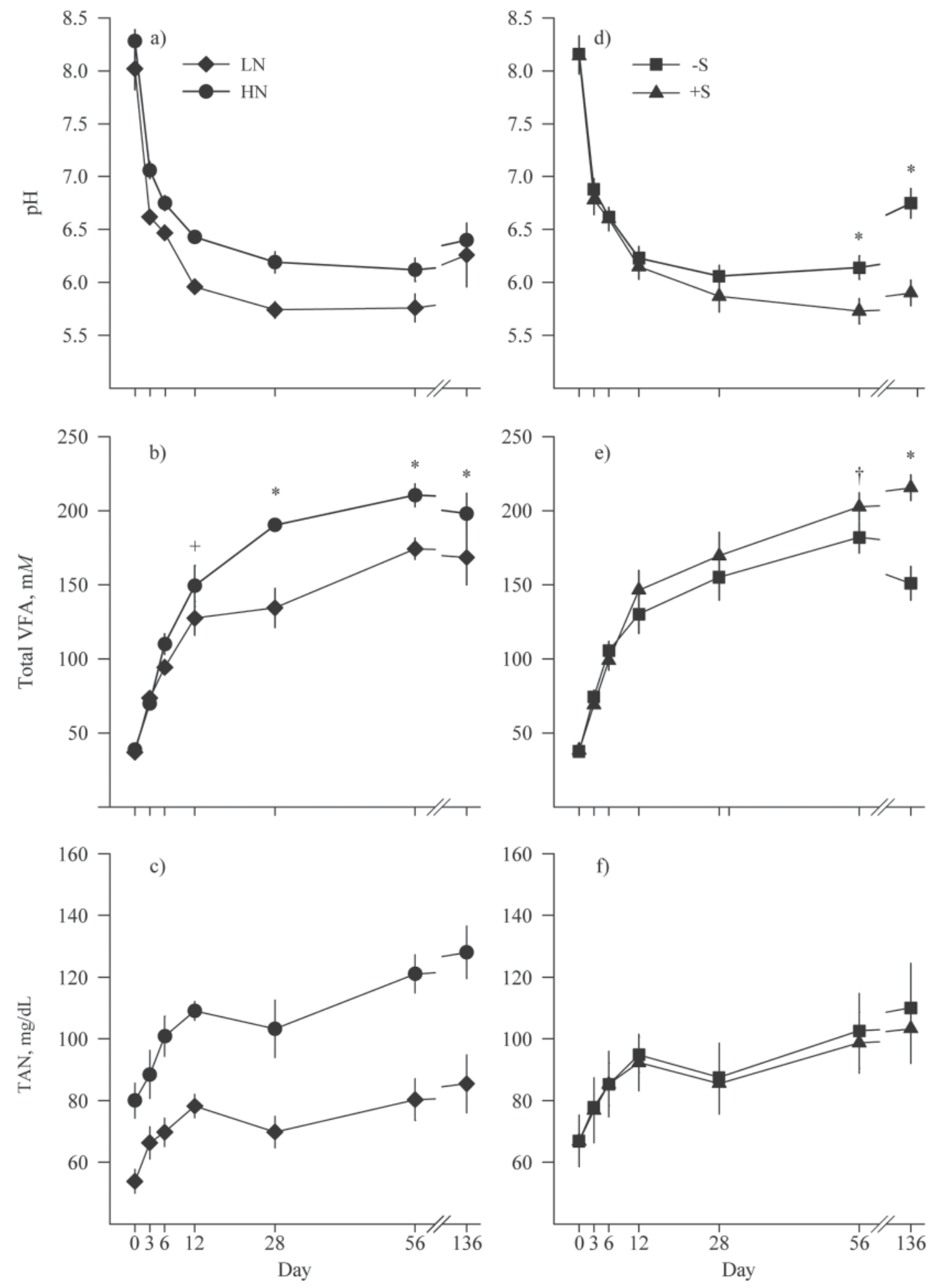

Figure 1. Change in manure composition during storage. Effect of manure $\mathrm{N}$ content (high $\mathrm{N}, \mathrm{HN}$, and low $\mathrm{N}, \mathrm{LN})$ on a) pH: manure $\mathrm{N}$ content $(P<0.01)$, day $(P<0.001)$, and manure N level $\times$ day $(P=0.45)$; b) total VFA (TVFA): manure $\mathrm{N}(P<0.01)$, day $(P<0.001)$, and manure $\mathrm{N} \times$ day $(P=0.012)$; $\mathrm{c})$ total ammonia $\mathrm{N}(\mathrm{TAN})$ : manure $\mathrm{N}(P<0.01)$, day $(P<0.001)$, and manure $\mathrm{N}$ level $\times$ day $(P=0.65)$; and effect of straw (with straw, $+\mathrm{S}$, and without straw, $-\mathrm{S})$ on d) pH: straw $(P=0.02)$, day $(P<0.001)$, and straw $\times$ day $(P<0.001)$; e) TVFA: straw $(P=0.04)$, day $(P<0.001)$, and straw $\times$ day $(P<0.001)$; and $f)$ TAN: straw $(P=0.74)$, day $(P<0.001)$, and straw $\times$ day $(P<0.99)$. When appropriate, treatment differences within a day are indicated by $* P<0.01,+P<0.05$, and $\dagger P<0.10$. Bars indicate SE. 


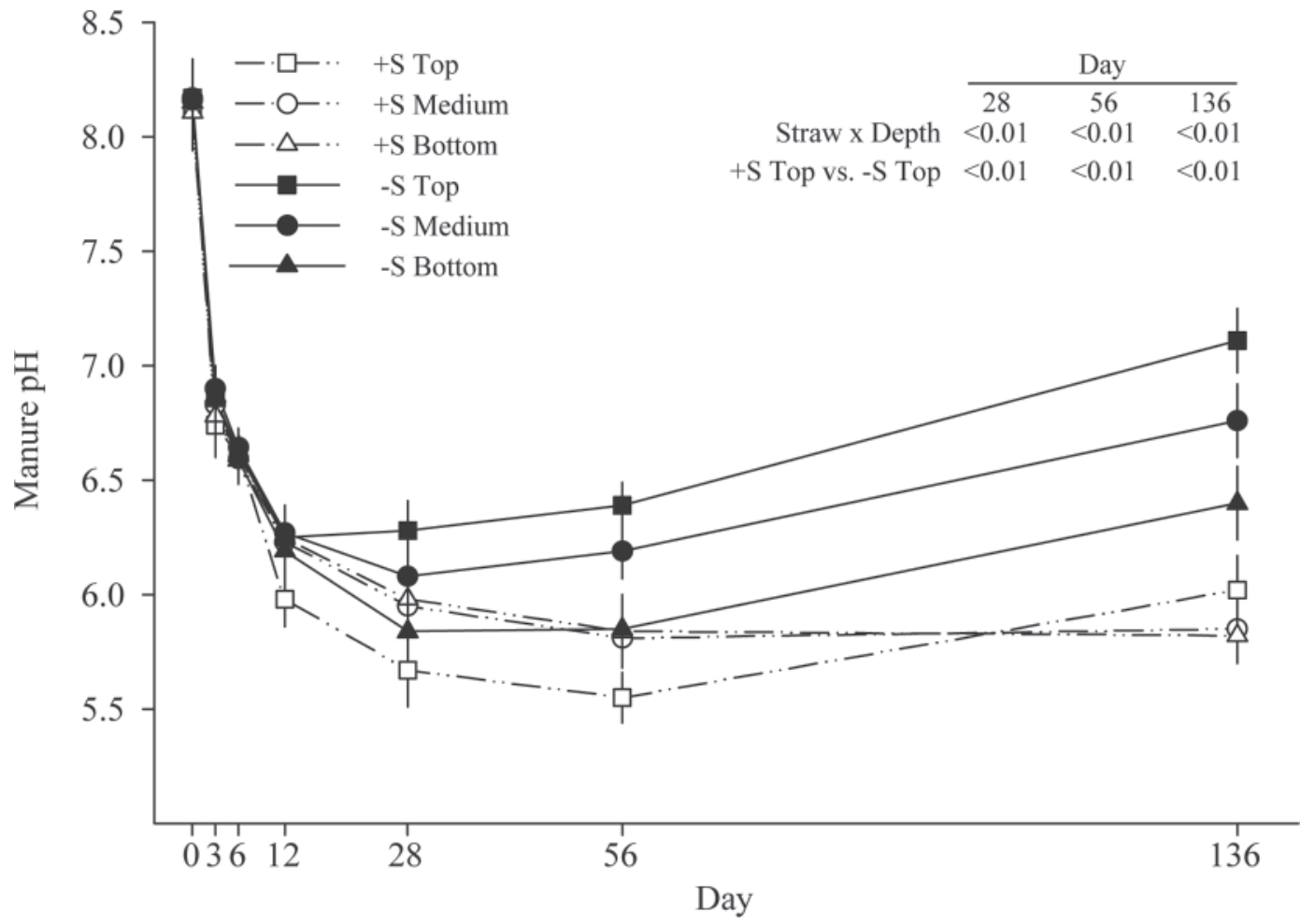

Figure 2. Effect of straw addition $(+\mathrm{S}$ and $-\mathrm{S})$ treatment on manure $\mathrm{pH}$ stratification (top, middle, and bottom). Bars indicate SE.
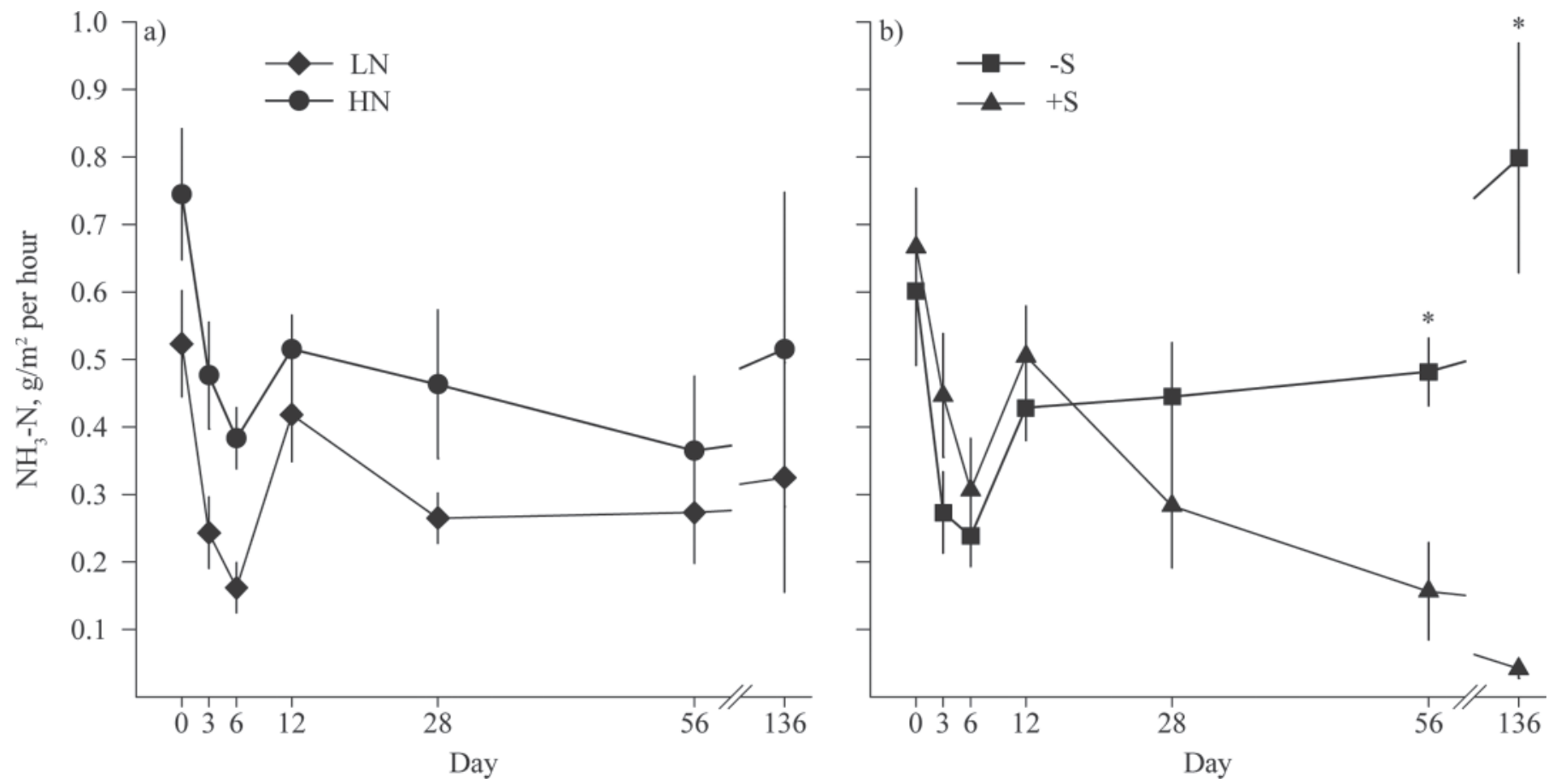

Figure 3. Change in $\mathrm{NH}_{3}-\mathrm{N}$ emission rate during storage: a) effect of manure $\mathrm{N}$ level (low $\mathrm{N}, \mathrm{LN}$, and high $\left.\mathrm{N}, \mathrm{HN}\right):$ manure $\mathrm{N}$ level $(P=$ $0.02)$, day $(P<0.001)$, and manure $\mathrm{N}$ level $\times$ day $(P=0.94)$; and $\mathrm{b})$ effect of straw addition $(+\mathrm{S}$ and $-\mathrm{S})$ : straw addition $(P=0.07)$, day $(P$ $<0.001)$, and straw addition $\times$ day $(P<0.001)$. When appropriate, treatment differences within a time point are indicated by $* P<0.01$. Bars indicate SE. 


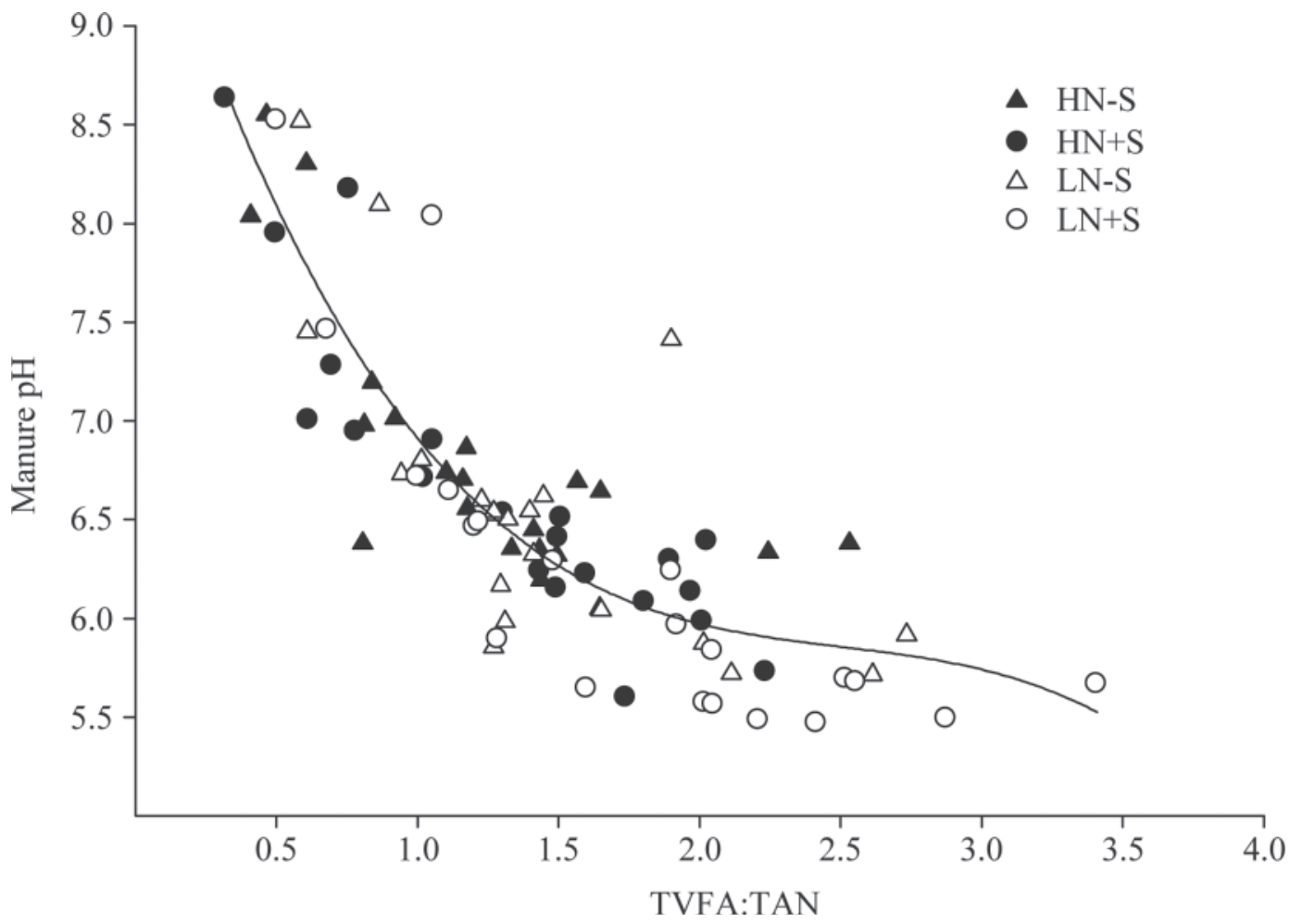

Figure 4. Relationship between manure $\mathrm{pH}$ and total VFA: total ammonia $\mathrm{N}\left(\right.$ TVFA:TAN) ratio $\left(\mathrm{y}=-4.57 \mathrm{x}+1.76 \mathrm{x}^{2}-0.23 \mathrm{x}^{3} ; \mathrm{R}^{2}=0.76\right.$; $\mathrm{n}=84)$. $\mathrm{HN}=$ high $\mathrm{N}$ manure, $\mathrm{LN}=$ low $\mathrm{N}$ manure, $+\mathrm{S}=$ with addition of straw, $-\mathrm{S}=$ no addition of straw.

0.57). The relationship between TVFA:TAN ratio and manure $\mathrm{pH}$ was curvilinear (Figure 4) and, under the conditions of this study, explained most of the observed differences in manure $\mathrm{pH}$.

\section{DISCUSSION}

\section{Effect of Manure N Content}

The average $36 \%$ reduction in $\mathrm{NH}_{3}-\mathrm{N}$ emission rate in response to lowering the manure $\mathrm{N}$ content in this study was smaller than the $69 \%$ reported by Kröber et al. (2000) for stored manure from a slatted floor barn.
However, in our trial, the initial difference in manure $\mathrm{N}$ was narrower than in Kröber et al. (2000). Furthermore, $\mathrm{NH}_{3}-\mathrm{N}$ losses likely occurred during the 6 - $\mathrm{h}$ period allowed for manure accumulation on the barn floor, whereas feces and urine were collected separately and combined immediately before storage in Kröber et al. (2000). In contrast, the $20 \% \mathrm{TN}$ loss reported here was similar to the $17.5 \%$ value reported by Kröber et al. (2000), albeit for a shorter period of storage (7 wk), but higher than the $8 \%$ gathered from the literature by Rotz (2004).

Muck (1982) showed that urea hydrolysis is rapid and contributes substantially to the TAN pool of ma-

Table 5. Correlation among manure chemical components $(\mathrm{n}=84)$

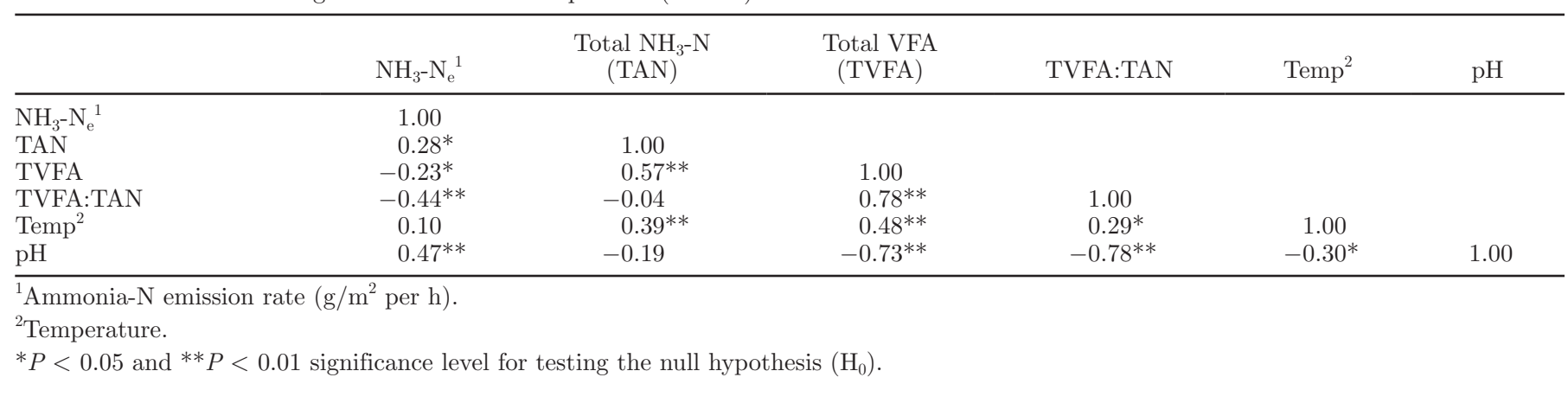


nure collected from barn floors. However, in accordance with the suggestion of Bussink and Oenema (1998), the continued increase in TAN for at least the first $12 \mathrm{~d}$ of storage observed here (Figures 1c and 1f) suggested that other N-containing compounds, such as purine derivatives, creatinine, creatine, and free amino acids, which may account for $16 \%$ of $\mathrm{TN}$ in urine (Bristow et al., 1992), constituted a slow-release source of $\mathrm{NH}_{3}-\mathrm{N}$ in manure. This conjecture was supported by results of soil studies that indicated slower rates of hydrolysis of these compounds relative to urea (Whitehead et al., 1989). The continued increase in TAN in the latter days of storage of this trial could be related to additional factors, including increased concentration due to evaporation of approximately $40 \mathrm{~kg}$ of water (Table 4) and the slow mineralization of a more recalcitrant form of organic N compound found in the feces. In this study, $29 \%$ of the organic $\mathrm{N}$ was mineralized during storage, a result that agreed with those of others (Patni and Jui, 1991; Thomsen, 2000), and extensive deamination was reflected in a 9.6-fold increase in branched-chain VFA concentration throughout storage (data not shown). Hence, the contribution of fecal $\mathrm{N}$ to the pool of TAN may have become more important as days of storage increased. This contention was supported by Thomsen (2000) and by Lee and Hristov (2010), who reported decreasing contributions of urinary $\mathrm{N}$ to $\mathrm{N}$ losses with increasing days of storage.

In the present study, the higher manure $\mathrm{pH}(0.26$ units) between $\mathrm{HN}$ and $\mathrm{LN}$ at the initiation of storage (Figure 1a) was probably associated with a higher content of urinary urea that was hydrolyzed into bases $\left(\mathrm{NH}_{3}\right.$ and $\left.\mathrm{CO}_{3}{ }^{2-}\right)$ and the subsequent emission of the more readily soluble $\mathrm{CO}_{2}$ (Sommer et al., 2006). This $\mathrm{pH}$ difference combined with the elevated TAN (Figure 1c) contributed to a higher $\mathrm{NH}_{3}-\mathrm{N}$ emission rate on the HN treatment (Figure 3a). Kröber et al. (2000) and Kulling et al. (2001) showed similar initial differences in manure $\mathrm{pH}$ and $\mathrm{NH}_{3}-\mathrm{N}$ emission from manure excreted by cows fed different dietary $\mathrm{CP}$ levels. With the exhaustion of the urea-originated $\mathrm{CO}_{2}$ release within the first few days of storage, manure $\mathrm{pH}$ decreased sharply and $\mathrm{NH}_{3}-\mathrm{N}$ emission decreased, in spite of an increase in TAN. Moreover, with the progressive establishment of anaerobic conditions, OM fermentation resulted in formation of TVFA (Figure 1b and 1c), which contributed to further decline in $\mathrm{pH}$. Higher content in organic $\mathrm{N}$ and TAN in HN compared with LN manure most likely contributed to buffering acids produced by fermentation (Patni and Jui, 1985), which may explain why, despite higher TVFA content, $\mathrm{pH}$ was consistently higher for HN relative to LN manure throughout storage (Figure 1a).
Hence, our results agreed with several studies that highlighted the importance of TVFA and TAN concentration as well as the effect of the $\mathrm{NH}_{4}{ }^{+} / \mathrm{NH}_{3}$ and $\mathrm{HCO}_{3}{ }^{-} / \mathrm{CO}_{3}$ buffering systems (Georgacakis et al., 1982; Sommer and Husted, 1995) in determining manure $\mathrm{pH}$ during storage. However, the linear relationship reported between $\mathrm{pH}$ and TVFA:TAN ratio in dairy manure (Paul and Beauchamp, 1989) and pig manure (Conn et al., 2007) contrasted with the curvilinear relationship found in this study (Figure 4).

\section{Effect of Straw}

Disruption of the air-liquid interface may cause resistance to transport and an almost immediate reduction in gaseous emission from manure storage units (VanderZaag et al., 2008). Previous studies (Xue at al., 1999; VanderZaag et al., 2009) have shown that wheat straw spread on top of manure effectively reduces $\mathrm{NH}_{3}-\mathrm{N}$ emissions during the initial days of storage, but that efficacy varies in the long-term, depending on the thickness of the resulting crust (Guarino et al., 2006; VanderZaag et al., 2008). Our study, however, was more comparable to that of Misselbrook et al. (2005a), who found no difference in rate of $\mathrm{NH}_{3}-\mathrm{N}$ emission due to bedding type (of unreported amounts), a result that conflicted with those of De Bode (1991), who observed greater emission reductions when larger amounts of straw were present in stored manure. When straw was mixed with the manure, as in this study, $\mathrm{NH}_{3}-\mathrm{N}$ emission rates were time-dependent and did not diverge significantly until crust formation (between d 12 and 28). The declining rate in $\mathrm{NH}_{3}-\mathrm{N}$ emission once the crust was formed (Figure 3b) was in agreement with Misselbrook et al. (2005a), who observed that crusts generally developed after 10 to $20 \mathrm{~d}$ of storage as suspended particles were carried by gas bubbles $\left(\mathrm{CO}_{2}\right.$ and $\left.\mathrm{CH}_{4}\right)$ to the surface. As a result, it was likely that, in this trial, the mixed straw did not exert its beneficial effect on $\mathrm{NH}_{3}-\mathrm{N}$ loss until after at least $28 \mathrm{~d}$ of storage and more so in the subsequent months.

In addition to its association with crust formation, reduction in $\mathrm{NH}_{3}-\mathrm{N}$ emission in the presence of straw was likely associated with a reduced $\mathrm{pH}$ at the emitting surface that altered the proportion of $\mathrm{NH}_{3} / \mathrm{NH}_{4}{ }^{+}$ in the solution during the latter months of storage, as suggested by Figure 1d and the $\mathrm{pH}$ stratification data of Figure 2. As a carbon source, straw may enhance anaerobic fermentation, driving down manure $\mathrm{pH}$ (Xue et al., 1999). In contrast, without straw and the resulting crust, manure $\mathrm{pH}$ on the surface was driven up because of direct contact with oxygen and aerobic conversion of TVFA to $\mathrm{CO}_{2}$ (Canh et al., 1998; Xue et al., 1999). 
Assuming a $p K_{\mathrm{a}}$ (logarithm of acid dissociation constant) of 9.25 (at $\left.25^{\circ} \mathrm{C}\right)$, the percentage of TAN $\left(\mathrm{NH}_{3}\right.$ $+\mathrm{NH}_{4}{ }^{+}$) in the form of $\mathrm{NH}_{3}$ at the manure surface on d 136 was predicted to be $0.72 \%$ in the absence of straw but $0.06 \%$ when straw was present. Furthermore, recent studies have confirmed the presence of $\mathrm{NH}_{3}$ and $\mathrm{CH}_{4}$-oxidizing bacteria in organic crusts (Petersen et al., 2005; Nielsen et al., 2010). Although these microbial processes might further contribute to decreasing emissions, they may also result in formation of nitrous oxide $\left(\mathrm{N}_{2} \mathrm{O}\right)$, a potent greenhouse gas (Hansen et al., 2009). Future research should evaluate the potential trade-offs between $\mathrm{NH}_{3}$ and greenhouse gases emissions from crust-covered manure.

\section{Rate of Emission Versus Mass Balance}

Each of the 2 contrasting methods for determining $\mathrm{N}$ losses has its strengths and pitfalls as applied under the conditions of this trial. Because we measured mass balance indoors, TN losses measured here might be low compared with those measured under outdoor storage conditions, where manure is exposed to variable environmental conditions, including solar heating, wind speed, and precipitation. In contrast, the rate of emission measured with the dynamic chambers might overestimate emissions because of the high air velocity used during measurement. The dynamic chamber technique is a valuable tool to evaluate treatment differences on $\mathrm{NH}_{3}-\mathrm{N}$ emission (Misselbrook et al., 2005b). However, this technique alters the microenvironment at the surface of exchange in unique ways (Fowler et al., 2001). In particular, air velocity and headspace turnover rate have a considerable effect on measurements. In this trial, the level of significance in rate of $\mathrm{NH}_{3}-\mathrm{N}$ emission due to manure $\mathrm{N}$ content (Figure $3 \mathrm{a}$ ) was not accompanied by the same significance in TN loss measured by mass balance over a 136-d storage period, although a $22 \%$ reduction in TN loss was observed for LN relative to HN manure. The explanation may lie in part with the statistical power associated with the design of this study but also with inherent differences between the 2 methods as described above. In this study, the highly variable rates of $\mathrm{NH}_{3}-\mathrm{N}$ emission among days of storage made estimates of cumulative emission using the AUC unreliable. For example, although the TN loss was 98, 108,129 , and $135 \mathrm{~g}$, the 136 - $\mathrm{d}$ cumulative $\mathrm{NH}_{3}-\mathrm{N}$ emissions derived from the AUC were 351, 98, 444, and $143 \mathrm{~g}$ for $\mathrm{LN}-\mathrm{S}, \mathrm{LN}+\mathrm{S}, \mathrm{HN}-\mathrm{S}$, and $\mathrm{HN}+\mathrm{S}$ treatments, respectively. Although in the presence of straw, we observed general agreement in derived estimates, the discrepancy between mass balance and AUC-derived estimates in the absence of straw is puzzling. The AUC analysis, however, showed that $32,66,32$, and $74 \%$ of the 136-d estimated $\mathrm{NH}_{3}-\mathrm{N}$ loss had occurred by d 56 for the $\mathrm{LN}-\mathrm{S}, \mathrm{LN}+\mathrm{S}, \mathrm{HN}-\mathrm{S}$, and $\mathrm{HN}+\mathrm{S}$ treatments, respectively, highlighting the importance of long-term sampling to evaluate treatment effects in manure storage studies.

\section{CONCLUSIONS}

In this trial, manure $\mathrm{N}$ level and addition of straw influenced rate of $\mathrm{NH}_{3}-\mathrm{N}$ emission because of their effects on fermentation pattern, as illustrated by changes in, and complex interaction among, $\mathrm{pH}$, TVFA, and TAN throughout a 136-d storage period. In addition, reducing manure $\mathrm{N}$ by $14 \%$ reduced the average $\mathrm{NH}_{3}-\mathrm{N}$ emission rate from stored manure by $36 \%$. The addition and mixing of wheat straw in amounts commonly used in freestall barns for bedding resulted in the formation of a crust between d 12 and 28 of storage. After the crust was formed, the $\mathrm{NH}_{3}-\mathrm{N}$ emission rate declined progressively and was essentially zero on d 136 . In this study, a reduction in rate of $\mathrm{NH}_{3}-\mathrm{N}$ emission was associated with only numerical decreases in total $\mathrm{N}$ loss measured by mass balance (albeit obtained from limited replications). The mass balance data indicated that the loss of volatile $\mathrm{C}$ was proportionally higher than the loss of volatile $\mathrm{N}$. The importance of a long-term storage trial was illustrated by the fact that differences in TVFA, manure $\mathrm{pH}$, and rate of $\mathrm{NH}_{3}-\mathrm{N}$ emission in response to some of the treatments did not occur until after 28 or $56 \mathrm{~d}$ of storage.

\section{ACKNOWLEDGMENTS}

This research was supported in part by the US Department of Agriculture National Institute of Food and Agriculture award no. 2009-51160-19789. The authors thank Randy Mertz and the employees of the Pioneer Farm (University of Wisconsin-Platteville) for feed preparation and animal care, University of WisconsinMadison students for helping during sample collection and processing, and laboratory manager Sandy Bertics (Department of Dairy Science, University of WisconsinMadison) for technical support.

\section{REFERENCES}

Aguerre, M. J., M. A. Wattiaux, T. Hunt, and B. R. Larget. 2010. Effect of dietary crude protein on ammonia-N emission measured by herd nitrogen mass balance in a free-stall dairy barn managed under farm-like conditions. Animal 4:1390-1400.

Bristow, A. W., D. C. Whitehead, and J. E. Cockburn. 1992. Nitrogenous constituents in the urine of cattle, sheep, and goats. J. Sci. Food Agric. 59:387-394.

Broderick, G. A. 2003. Effects of varying dietary protein and energy levels on the production of lactating dairy cows. J. Dairy Sci. $86: 1370-1381$. 
Bussink, D. W., and O. Oenema. 1998. Ammonia volatilization from dairy farming systems in temperate areas: A review. Nutr. Cycl. Agroecosyst. 51:19-33.

Canh, T. T., A. L. Sutton, A. J. A. Aarnink, M. W. A. Verstegen, J. W. Schrama, and G. C. M. Bakker. 1998. Dietary carbohydrates alter fecal composition and $\mathrm{pH}$ and the ammonia emission from slurry of growing pigs. J. Anim. Sci. 76:1887-1895.

Chaney, A. L., and E. P. Marbach. 1962. Modified reagents for determination of urea and ammonia. Clin. Chem. 8:130-132.

Conn, K. L., E. Topp, and G. Lazarovits. 2007. Factors influencing the concentration of volatile fatty acids, ammonia, and other nutrients in stored liquid pig manure. J. Environ. Qual. 36:440-447.

De Bode, M. J. C. 1991. Odour and ammonia emissions from manure storage. Pages 59-66 in Proceedings: Odour and Ammonia Emissions from Livestock Farming, Silsoe, UK. V. C. Nielsen, J. H. Voorburg, and P. L'Hermite, ed. Elsevier Applied Science, London, UK

EPA. 2005. National Emission Inventory-Ammonia emissions from animal husbandry operations. Revised Draft Report, April 2005. Accessed July 13, 2010. http://www.epa.gov/ttn/chief/ap42/ ch09/index.html.

Fangmeier, A., A. Hadwigerfangmeier, L. Vandereerden, and H. J. Jager. 1994. Effect of atmospheric ammonia on vegetation-A review. Environ. Pollut. 86:43-82.

FAO. 2006. Livestock's Long Shadow. Environmental issues and options. Accessed July 13, 2010. http://www.fao.org/docrep/010/ a0701e/a0701e00.htm.

Fowler, D., M. Coyle, C. Flechard, K. Hargreaves, E. Nemitz, R. Storeton-West, M. Sutton, and J. W. Erisman. 2001. Advances in micrometeorological methods for the measurement and interpretation of gas and particle nitrogen fluxes. Plant Soil 228:117-129.

Georgacakis, D., D. M. Sievers, and E. L. Ianotti. 1982. Buffer stability in manure digesters. Agric. Waste 4:427-441.

Guarino, M., C. Fabbri, M. Brambilla, L. Valli, and P. Navarro. 2006. Evaluation of simplified covering systems to reduce gaseous emissions from livestock manure storage. Trans. ASAE 49:737-747.

ASHRAE (American Society of Heating, Refrigerating and Air-Conditioning). 1993. ASHRAE Handbook: Fundamentals. ASHRAE, Atlanta, GA.

Hansen, R. R., D. A. Nielsen, A. Schramm, L. P. Nielsen, N. P. Revsbech, and M. N. Hansen. 2009. Greenhouse gas microbiology in wet and dry straw crust covering pig slurry. J. Environ. Qual. 38:1311-1319.

Kröber, T. F., D. R. Kulling, H. Menzi, F. Sutter, and M. Kreuzer. 2000. Quantitative effects of feed protein reduction and methionine on nitrogen use by cows and nitrogen emission from slurry. J. Dairy Sci. 83:2941-2951.

Kulling, D. R., H. Menzi, T. F. Krober, A. Neftel, F. Sutter, P. Lischer, and M. Kreuzer. 2001. Emissions of ammonia, nitrous oxide and methane from different types of dairy manure during storage as affected by dietary protein content. J. Agric. Sci. (Camb.) $137: 235-250$

Lee, C., and A. N. Hristov. 2010. Origin of ammonia nitrogen volatilized from dairy manure. J. Dairy Sci. 93(E-Suppl. 1):691. (Abstr.)

Midwest Plan Service. 1995. Dairy Freestall Housing and Equipment. 5th ed. Iowa State University, Ames.

Misselbrook, T. H., S. K. E. Brookman, K. A. Smith, T. Cumby, A. G. Williams, and D. F. McCrory. 2005a. Crusting of stored dairy slurry to abate ammonia emissions: Pilot-scale studies. J. Environ. Qual. 34:411-419.
Misselbrook, T. H., J. M. Powell, G. A. Broderick, and J. H. Grabber 2005b. Dietary manipulation in dairy cattle: Laboratory experiments to assess the influence on ammonia emissions. J. Dairy Sci. 88:1765-1777.

Muck, R. E. 1982. Urease activity in bovine feces. J. Dairy Sci. $65: 2157-2163$

NRC. 2001. Nutrient Requirements of Dairy Cattle. 7th rev. ed. Natl Acad. Press, Washington, DC.

Nielsen, D. A., L. P. Nielsen, A. Schramm, and N. P. Revsbech. 2010 Oxygen distribution and potential ammonia oxidation in floating, liquid manure crusts. J. Environ. Qual. 39:1813-1820.

Patni, N. K., and P. Y. Jui. 1985. Volatile fatty acids in stored dairy cattle slurry. Agric. Waste 13:159-178.

Patni, N. K., and P. Y. Jui. 1991. Nitrogen concentration variability in dairy-cattle slurry stored in farm tanks. Trans. ASAE 34:609615.

Paul, J. P., N. E. Dinn, T. Kannangara, and L. J. Fisher. 1998. Protein content in dairy cattle affects ammonia losses and fertilizer nitrogen value. J. Environ. Qual. 27:528-534.

Paul, J. W., and E. G. Beauchamp. 1989. Relationship between volatile fatty acids, total ammonia and $\mathrm{pH}$ in manure slurries. Biol. Waste 29:313-318.

Petersen, S. O., B. Amon, and A. Gattinger. 2005. Methane oxidation in slurry storage surface crust. J. Environ. Qual. 34:455-461.

Rotz, C. A. 2004. Management to reduce nitrogen losses in animal production. J. Anim. Sci. 82(E-Suppl.):E119-E137.

SAS Institute. 2004. SAS/STAT User's Guide. SAS Institute Inc. Cary, NC.

Sommer, S. G., and S. Husted. 1995. The chemical buffer system in raw and digested animal slurry. J. Agric. Sci. (Camb.) 124:45-53.

Sommer, S. G., G. Q. Zhang, A. Bannik, D. Chadwick, T. Misselbrook, R. Harrison, N. J. Hutchings, H. Menzi, G. J. Monteny, J. Q. Ni, O. Oenema, and J. Webb. 2006. Algorithms determining ammonia emission form buildings housing cattle and pigs and from manure stores. Adv. Agron. 89:261-335.

Thomsen, I. K. 2000. C and N transformations in ${ }^{15} \mathrm{~N}$ cross-labelled solid ruminant manure during anaerobic and aerobic storage. Bioresour. Technol. 72:267-274.

Van Soest, P. J., J. B. Robertson, and B. A. Lewis. 1991. Methods for dietary fiber, neutral detergent fiber, and non-starch polysaccharides in relation to animal nutrition. J. Dairy Sci. 74:3583-3597.

VanderZaag, A. C., R. J. Gordon, V. M. Glass, and R. C. Jamieson 2008. Floating covers to reduce gas emissions from liquid manure storages: A review. Appl. Eng. Agric. 24:657-671.

VanderZaag, A. C. R. J. Gordon, R. C. Jamieson, D. L. Burton, and G. W. Stratton. 2009. Gas emission from straw covered liquid dairy manure during summer storage and autumn agitation. Trans. ASABE 52:599-608.

Wattiaux, M. A., and K. L. Karg. 2004. Protein level for alfalfa and corn silage-based diets: II. Nitrogen balance and manure characteristics. J. Dairy Sci. 87:3492-3502.

Whitehead, D. C., D. R. Lockyer, and N. Raistrick. 1989. Volatilisation of ammonia from urea applied to soil: Influence of hippuric acid and other constituents of livestock urine. Soil Biol. Biochem. 21:803-808.

Xue, S. K., S. Chen, and R. E. Hermanson. 1999. Wheat straw cover for reducing ammonia and hydrogen sulfide emissions from dairy manure storage. Trans. ASAE 42:1095-1101. 